\title{
ETIKA POLITIK DALAM ISLAM
}

\section{Muh. In'amuzzahidin}

Dalam dunia politik praktis, terkesan tidak ada etikanya. Karena yang dikejar adalah tercapainya tujuan politik dengan segala cara. Namun dalam Islam, ada etika politik yang telah dibangun oleh para pemikir muslim, seperti Ibn Abi Rabi' al-Farabi alMawardi Ibn Taymiyyah, dapat dijadikan sebagai bahan renungan, acuan, dan evaluasi terhadap kehidupan politik yang ada, tak terkecuali kehidupan berpolitik di Indonesia, sekaligus diterapkan secara riil dalam panggung politik, dengan multi-interpretasinya. Dengan beretika dalam politik, diharapkan kehidupan politik yang ada menjadi lebih santun dan membawa kemaslahatan bagi rakyat.

Keyword : etika, politik, al-siyâsah, ahl al-'aqd wa al-hal 


\section{A. Pendahuluan}

Sebuah pemerintahan akan berjalan efektik, jika dipegang oleh pemimpin-pemimpin yang amanah. Baik pemerintah daerah maupun pusat. Dalam kontek ke-Indonesia-an, pemimpin dipilih oleh rakyat melalui mekanisme pemilu. Dengan harapan, pemilihan umum tersebut akan melahirkan pemimpin-pemimpin yang sesuai dengan harapan rakyat, yang lebih mementingkan kepentingan rakyat daripada kepentingan kelompok atau dirinya sendiri.

Idealnya, calon pemimpin yang jadi adalah orang yang berkualitas secara keilmuan dan pengalaman dalam memimpin. Namun realitas berbicara lain. Siapa yang dapat mendapatkan dukungan suara yang paling banyak dan memenuhi persyaratan batas atas minimal perolehan suara-lah yang mendapatkan jatah kursi tersebut. Meskipun, dalam proses perolehan suara itu terdapat intrik-intrik money politic atau yang lain, tidak terlalu dipersoalkan. Padahal, jika pemimpin lahir dari proses pemilihan yang mengeluarkan banyak dana, maka dapat dipastikan, kelak ia pasti ingin mengembalikan modal yang telah ia keluarkan dan cenderung koruptif.

Belum lagi adanya kampanye hitam (black campaign) pun seolah dilegalkan, demi mengalahkan kandidat lain dan mendapat simpati dari rakyat. Aturan-aturan proses penjaringan calon kandidat pun, konon juga dapat di-setting sesuai dengan yang diinginkan oleh pihakpihak tertentu.

Dengan melihat realitas politik yang ada di atas, seolah-olah etika politik sudah tidak berlaku lagi, bahkan dapat dikatakan tidak ada. Etika politik hanya dibicarakan dalam tataran teori saja. Dalam politik, seolah-olah, yang ada adalah tujuan politik tercapai dengan segala cara, bahkan menghalalkan segala cara. Benarkah demikian? Tulisan ini akan mencoba mengabstraksikan beberapa pemikiran etika politik dalam Islam, yang terfokus pada pemikiran politik klasik dan pertengahan awal, dan relevansinya dengan kondisi perpolitikan di Indonesia dewasa ini.

\section{B. Batasan dan Ruang Lingkup Etika Politik}

Untuk mengetahui lebih jelas tentang definisi etika politik, ada baiknya jika kita jelaskan dahulu, apa itu etika dan apa itu politik.

Istilah etika, berasal dari bahasa Yunani kuno. Dalam bentuk tunggal, kata Yunani ethos mempunyai banyak arti, yakni : tempat tinggal yang biasa; padang rumput, kandang; kebiasaan, adat; akhlak, watak; perasaan, sikap, cara berpikir. Arti terakhir inilah, yang menjadi latar belakang terbentuknya istilah 'etika', yang oleh Aristoteles (384-322 SM) - filosof besar Yunani - sudah dipakai untuk menunjukkan filsafat moral. Dari arti etimologis etika di atas, maka etika dapat diartikan sebagai ilmu tentang apa yang biasa dilakukan atau ilmu tentang adat kebiasaan. ${ }^{1}$

Adapun kata yang dekat maknanya dengan etika adalah 'moral'. Kata moral berasal dari bahasa Latin mos (jamak : mores), yang dapat berarti kebiasaan atau adat. Sehingga kedua kata tersebut, secara etimologis, mempunyai arti yang sama, yakni adat kebiasaan. Hanya saja, asal usul kedua kata tersebut berbeda. Kata etika berasal dari bahasa Yunani, sedang kata moral

1 K. Bertens, 2000, Etika, Gramedia, Jakarta, cet. V, hlm. 4 
berasal dari bahasa Latin. ${ }^{2}$

Sedangkan secara terminologis - sebagaimana diungkapkan dalam Kamus Besar Bahasa Indonesia - kata etika dapat dibedakan menjadi tiga arti, yaitu : 1) ilmu tentang apa yang baik dan apa yang buruk, dan tentang hak dan kewajiban moral (akhlak); 2) kumpulan asas atau nilai yang berkenaan dengan akhlak; 3) nilai mengenai benar dan salah yang dianut suatu golongan dan masyarakat. ${ }^{3}$

Sejalan dengan statemen di atas, John L. Esposito mengungkapkan, bahwa term ethic (etika) merupakan studi yang berkaitan dengan practical justification. Focus etika adalah mengabstraksikan dan mengevaluasi reason personal atau kelompok tertentu, yang memberikan judgment kepada mereka, tentang benar-salah, atau baik-buruk, yang biasanya berkaitan dengan perbuatan manusia (buman act), sikap (attitudes) dan kepercayaan (belief) mereka. ${ }^{4}$

Kemudian kata moral, secara terminologis, menurut Bertens, sama dengan etika meskipun mempunyai arti lain - yaitu : nilai-nilai dan norma-norma yang menjadi pegangan bagi seseorang atau kelompok dalam mengatur tingkah lakunya. ${ }^{5}$

Namun ada juga yang membedakan kedua istilah tersebut (etika dan moral). Moral selalu dikaitkan dengan kewajiban khusus, dihubungkan dengan norma sebagai cara bertindak yang berupa tuntutan, baik bersifat relatif maupun mutlak. Moral merupakan wacana normatif dan imperatif yang diungkapkan dalam kerangka yang baik dan yang buruk, yang dianggap sebagai nilai mutlak atau transenden, yakni seluruh kewajiban-kewajiban kita. Sehingga kata moral mengacu pada baik-buruknya manusia, yang berkaitan dengan tindakan, sikap, cara mengungkapkannya. Moral ingin menjawab “apa yang harus saya lakukan?”. Jadi, konsep moral mengandung dua makna. Pertama, keseluruhan aturan dan norma yang berlaku, yang diterima oleh masyarakat tertentu sebagai arah atau pegangan dalam bertindak, dan diungkapkan dalam kerangka yang baik dan yang buruk. Kedua, disiplin filsafat yang merefleksikan aturan-aturan tersebut, dalam rangka mencari pendasaran dan tujuan atau finalitasnya. Arti ke dua inilah yang lebih dekat dengan konsep etika. ${ }^{6}$

Sedangkan etika, biasanya dipahami sebagai refleksi filosofis tentang moral. Etika lebih merupakan wacana normatif, tetapi tidak selalu imperatif, karena juga bisa hipotesis, yang membicarakan pertentangan antara yang baik dan yang buruk, yang dianggap sebagai nilai relatif. Etika ingin menjawab pertanyaan "bagaimana hidup yang baik?". Sehingga etika lebih dipandang sebagai seni hidup yang mengarah kepada kebahagiaan dan puncaknya adalah kebijakan. ${ }^{7}$

2 K. Bertens, 2000, Etika, Gramedia, Jakarta, cet. V, hlm. 5

3 K. Bertens, 2000, Etika, Gramedia, Jakarta, cet. V, hlm. 5-6; Tim Penyusun Kamus Pusat Pembinaan dan Pengembangan Bahasa, 1988, Kamus Besar bahasa Indonesia, Departemen Pendidikan dan Kebudayaan, Balai Pustaka, Jakarta, cet. I, hlm. 237

4 John L Esposito (Ed), 1995, The Oxford Encyclopedia of The Modern Islamic World, Oxford University Press, New York, vol. 1, hlm. 442

5 K. Bertens, 2000, Etika, Gramedia, Jakarta, cet. V, hlm. 7

6 Haryatmoko, 2004, Etika Politik dan Kekerasan, Kompas, Jakarta, cet. II, hlm. 187

7 Haryatmoko, 2004, Etika Politik dan Kekerasan, Kompas, Jakarta, cet. II, hlm. 187 
Selanjutnya, istilah politik biasa menunjukkan pada masyarakat secara keseluruhan. Sebuah keputusan dianggap bersifat politis, apabila keputusan tersebut diambil dengan memperhatikan kepentingan masyarakat keseluruhan. Suatu tindakan disebut politis, apabila menyangkut masyarakat secara keseluruhan. Politisi adalah seseorang yang mempunyai profesi mengenai masyarakat sebagai keseluruhan. ${ }^{8}$

Sedangkan dalam Kamus Besar bahasa Indonesia, kata politik diartikan sebagai berikut ; 1) (ilmu) pengetahuan tentang ketatanegaraan atau kenegaraan (seperti sistem pemerintah, dasardasar pemerintah); 2) segala urusan dan tindakan (kebijakan, siasat dan sebagainya) mengenai pemerintahan negara atau terhadap negara lain; dalam dan luar negeri. Kedua negara itu bekerja sama di bidang ekonomi dan kebudayaan, partai atau organisasi; 3) kebijakan; cara bertindak (dalam menghadapi atau menangani masalah). ${ }^{9}$

Dalam bahasa arab, kata politik biasa disebut dengan al-siyâsah. Al-siyâsah merupakan bentuk mashdar dari kata kerja sâsa-yasûsu, yang pelakunya disebut sầis. Secara etimologis, kata al-siyâsah dapat berarti mengatur, mengurus, dan memerintah. ${ }^{10}$ Siyâsah juga bisa berarti pemerintahan dan politik atau membuat kebijaksanaan. ${ }^{11}$

Secara terminologis, siyâsah adalah mengatur atau memimpin sesuatu dengan cara yang membawa kemashlahatan; ${ }^{12}$ atau membuat kemashlahatan manusia dengan membimbing mereka ke jalan yang menyelamatkan. Siyâsah adalah ilmu pemerintahan untuk mengendalikan tugas dalam negeri dan luar negeri, yaitu politik dalam negeri dan politik luar negeri serta kemasyarakatan, yakni mengatur kehidupan umum berdasarkan keadilan dan istiqamah. ${ }^{13}$ Atau mudahnya, siyâsah artinya kewajiban menangani sesuatu yang mendatangkan kemashlahatan; mengatur dan menangani urusan rakyat dan mendatangkan kemashlahatan bagi mereka. ${ }^{14}$

Dari berbagai definisi etika dan politik yang telah penulis jelaskan di atas, maka dapat dikatakan, bahwa etika politik artinya kumpulan nilai yang berkenaan dengan akhlak, untuk mengatur atau memimpin sesuatu dengan cara yang membawa kemashlahatan. Dan etika politik itu merupakan filsafat moral tentang dimensi politis kehidupan manusia. ${ }^{15}$

Dalam masyarakat, fungsi etika politik terbatas pada penyediaan alat-alat teoritis untuk mempertanyakan dan menjelaskan legitimasi politik secara bertanggung jawab; tidak berdasarkan emosi, prasangka, dan apriori, tetapi secara rasional, obyektif, dan argumentatif.

8 Franz Magnis Suseno, 2003, Etika Politik, Gramedia, Jakarta, cet. VII, hlm. 19-20

9 Tim Penyusun Kamus Pusat Pembinaan dan Pengembangan Bahasa, 1988, Kamus Besar bahasa Indonesia, Departemen Pendidikan dan Kebudayaan, Balai Pustaka, Jakarta, cet. I, hlm. 694

10 Jamâl al-Dîn Muhammad Ibn Mukarram al-Anshârî Ibn Manzhûr, 1968, Lisân al-Arab, juz VI, Dâr alMasyriq, Bairut, hlm. 108; Luwîs Ma'lûf, 1986, al-Munjid fí al-Lughah wa al-A lam, Dâr al-Masyriq, Bairut, hlm. 362

11 Abd al-Wahhâb Khallâf, 1977, al-Siyâsah al-Syariiyyah, Dâr al-Anshâr, Kairo, hlm. 4

12 Ibn Manzhûr, 1968, Lisân al-Arab, juz VI, Dâr al-Masyriq, Bairut, hlm. 108

13 Luwîs Ma lûf, 1986, al-Munjid fî al-Lughah wa al-A lam, Dâr al-Masyriq, Bairut, hlm. 362

14 Yusuf al-Qardhawi, 1999, ,Pedoman Bernegara Dalam Perspektif Islam, terj. Kathur Suhardi, Pustaka alKautsar, Jakarta, cet. II, hlm. 34-35; J. Suyuthi Pulungan, 1999, Fiqih Siyasah, Ajaran Sejarah dan Pemikiran, Raja Grafindo, Jakarta, cet. IV, hlm. 22-23

15 Franz Magnis Suseno, 2003, Etika Politik, Gramedia, Jakarta, cet. VII, hlm. 8 
Manfaat etika politik tidaklah bersifat praktis. Ia tidak bertugas mengkhutbahi para politisi atau untuk langsung mempertanyakan legitimasi moral berbagai keputusan. Tetapi, etika politik menuntut agar segala klaim atas hak untuk menata masyarakat dipertanggungjawabkan pada prinsip-prinsip moral dasar. Etika politik dapat memberikan patokan-patokan orientasi dan pegangan normative bagi mereka yang memang mau menilai kualitas tatanan dan kehidupan politik dengan tolok ukur martabat manusia. ${ }^{16}$ Karenanya, inti permasalahan etika politik adalah masalah legitimasi etis kekuasaan yang dapat dirumuskan dalam pertanyaan : dengan hak moral apa seseorang atau kelompok orang memegang dan mempergunakan kekuasaan yang mereka miliki. Setiap penguasa selalu dihadapkan dengan tuntutan untuk mempertanggung jawabkannya. Dan apabila pertanggung jawaban itu tidak diberikan, maka kekuasaan itu tidak lagi dianggap sah. ${ }^{17}$

Etika politik tidak hanya menyangkut masalah perilaku politikus, tetapi juga berhubungan dengan praktik institusi social, hukum, komunitas, struktur-struktur sosial, politik, ekonomi. Karena, perilaku politikus hanya salah satu dimensi etika politik. Sebuah kehendak yang baik, perlu didukung institusi yang adil. Dan kehendak baik berfungsi mempertajam makna tanggung jawab, sedangkan institusi (hukum, aturan, kebiasaan, lembaga sosial) berperan mengorganisir tanggung jawab. ${ }^{18}$

Atau dengan kata lain, etika politik mengandung aspek individu dan aspek sosial. Satu sisi, etika politik adalah etika individu dan etika social sekaligus. Disebut etika individu, karena ia membahas masalah kualitas moral pelaku; dan disebut etika sosial, karena ia merefleksikan masalah hukum, tatanan sosial, dan institusi yang adil. Di sisi lain, etika politik adalah etika institusional dan etika keutamaan sekaligus. Institusi dan keutamaan merupakan dua dimensi etika yang saling mendukung. Keutamaan merupakan faktor stabilisasi tindakan yang berasal dari dalam diri pelaku; sedangkan institusi menjamin stabilitas dari luar diri pelaku. ${ }^{19}$

Selain itu, etika politik ini memiliki tiga dimensi : pertama adalah tujuan politik; ke dua berhubungan dengan masalah pilihan sarana; ke tiga berhadapan dengan aksi politik, yang terkait langsung dengan perilaku politikus.

Dimensi tujuan, terumuskan dalam upaya mencapai kesejahteraan masyarakat dan hidup damai yang didasarkan pada kebebasan dan keadilan. Atau dengan kata lain, tujuan etika politik adalah mengarahkan ke hidup yang baik, bersama dan untuk orang lain, dalam rangka memperluas lingkup kebebasan dan membangun institusi-institusi yang adil.. ${ }^{20}$ Dan kendala utama dalam masalah ini adalah upaya penerapan kebijakan umum (policy) dalam manajemen publik. Berdasarkan kebijakan umum ini, wakil rakyat dan kelompok-kelompok masyarakat dapat membuat evaluasi pelaksanaan kinerja pemerintah dan menuntut pertanggungjawaban. Kejelasan tujuan yang tertuang dalam kebijakan publik tersebut, menunjukkan ketajaman visi

16 Franz Magnis Suseno, 2003, Etika Politik, Gramedia, Jakarta, cet. VII, hlm. 2-5

17 Franz Magnis Suseno, 2003, Etika Politik, Gramedia, Jakarta, cet. VII, hlm. 22-30

18 Haryatmoko, 2004, Etika Politik dan Kekerasan, Kompas, Jakarta, cet. II, hlm. 25

19 Haryatmoko, 2004, Etika Politik dan Kekerasan, Kompas, Jakarta, cet. II, hlm. 25

20 Haryatmoko, 2004, Etika Politik dan Kekerasan, Kompas, Jakarta, cet. II, hlm. 204 
sang pemimpin dan kepedulian suatu partai politik terhadap aspirasi masyarakat. Dan dimensi moralnya adalah terletak pada kemampuan menentukan arah yang jelas terhadap kebijakan umum dan akuntabilitasnya. ${ }^{21}$

Dimensi sarana - yang memungkinkan pencapaian tujuan - meliputi system dan prinsipprinsip dasar pengorganisasian praktik penyelenggaraan negara dan yang mendasari institusiinstitusi sosial, yang ikut menentukan pengaturan perilaku masyarakat dalam menghadapi masalah-masalah dasar. Pola-pola tersebut mengandung imperatif normatif yang disertai sangsi. Dimensi sarana (polity) ini, mengandung dua pola normatif. Pertama, tatanan politik (hukum dan institusi) harus mengikuti prinsip solidaritas dan subsidiaritas, penerimaan pluratitas; struktur sosial ditata secara politik menurut prinsip keadilan. Karena itu, asas kesamaan dan masalah siapa yang diuntungkan atau siapa yang dirugikan oleh hukum atau institusi tertentu, relevan untuk dibahas. Ke dua, kekuatan-kekuatan politik ditata sesuai dengan prinsip timbal balik. Dimensi moral pada tingkat sarana ini, terletak pada peran etika dalam menguji dan mengkritisi legitimasi keputusan-keputusan, institusi-institusi dan praktik-praktik politik. ${ }^{22}$

Sedangkan dalam dimensi aksi politik, pelaku memegang peran sebagai penentu rasionalitas politik, yang terdiri dari rasionalitas tindakan dan keutamaan (kualitas moral pelaku). Sebuah tindakan politik dapat dikatakan rasional, apabila pelakunya mempunyai orientasi situasi dan paham permasalahan. Hal ini sangat tergantung pada kemampuan pelakunya, untuk mempersepsi kepentingan-kepentingan yang dipertaruhkan, berdasarkan peta kekuatan politik yang ada. Dan disposisi kekuasaan ini membantu untuk memperhitungkan kemampuan dan dampak aksi politiknya. Karenanya, penguasaan manajemen konflik adalah syarat aksi politik yang etis. Dan aksi, mengandaikan keutamaan; penguasaan diri dan keberanian memutuskan serta menghadapi risikonya; fair dan adil dalam hubungan dengan yang lain. Pada dimensi aksi ini, etika identik dengan tindakan yang rasional dan bermakna. Politik mempunyai makna, karena memperhitungkan reaksi yang lain; seperti harapan, protes, kritik, persetujuan, atau penolakan. Dan makna etis akan semakin dalam, ketika tindakan politikus didasari oleh pembelaan dan keberpihakan kepada kaum yang lemah atau korban. ${ }^{23}$

\section{Pemikiran Etika Politik Dalam Islam}

Dunia ilmu pengetahuan, pada masa pemerintahan Abbasiyah, mengalami zaman keemasannya, khususnya dalam dua ratus tahun pertama dari lima ratus tahun kekuasaan dinasti ini. Khalifah ke tujuh, Makmun, sangat besar perhatiannya kepada pengembangan ilmu pengetahuan, yang yang berkaitan dengan ilmu-ilmu agama dan social maupun ilmu pasti dan ilmu alam. Dia juga dikenal pengagum ilmu-ilmu Yunani, termasuk filsafat. Untuk melengkapi dan mendukung kebutuhan keilmuan, ia mendirikan perpustakaan Bait al-Hikmah, dengan buku-buku asing juga buku-buku Islam. Dari sinilah, perkenalan para ilmuwan Islam dengan alam pikiran Yunani semakin meluas dan mendalam, yang pada saatnya nanti akan menimbulkan

21 Haryatmoko, 2004, Etika Politik dan Kekerasan, Kompas, Jakarta, cet. II, hlm. 25-27

22 Haryatmoko, 2004, Etika Politik dan Kekerasan, Kompas, Jakarta, cet. II, hlm. 27

23 Haryatmoko, 2004, Etika Politik dan Kekerasan, Kompas, Jakarta, cet. II, hlm. 28 
hasrat sarjana-sarjana Islam untuk mempelajari msalah-msalah kenegaraan secara rasional. Maka lahirlah pemikir-pemikir muslim yang mengemukakan konsepsi politiknya melalui karyakaryanya. ${ }^{24}$ Dalam pembahasan pemikiran etika politik ini, penulis batasi hanya pada pemikiran politik pada masa klasik dan pertengahan awal. ${ }^{25}$

\section{Pemikiran Ibn Abi Rabi’}

Nama lengkapnya adalah Syihab al-Din Aḥmad Ibn Muhammad Ibn Abi Rabi'. Pemikirin politiknya terlihat dalam karyanya yang berjudul suluk al-Malik $f i$ Tadbir al-Mamalik (perilaku raja dalam pengelolaan kerajaan-kerajaan), yang ditulis untuk memenuhi permintaan khalifah al-Mu'tashim, khalifah ke delapan dinasti Abbasiyyah, yang memerintah abad IX Masehi. ${ }^{26}$

Menurut Ibn Abi Rabi', asal mula tumbuhnya kota atau terbentuknya negara, berasal dari ketidak berdayaan manusia untuk hidup sendiri dalam mencukupi segala kebutuhan hidupnya, tanpa bantuan orang lain. Ketergantungan kepada orang lain inilah, mendorong manusia untuk saling membantu dan berkumpul, serta menetap di satu tempat. Dari sinilah, tumbuh sebuah komunitas kota, yang akhirnya berkembang menjadi sebuah negara. ${ }^{27}$

Kekuasaan kepala negara, bagi Ibn Abi Rabi', adalah bersumber dari Tuhan. Hal ini dapat dipahami dari statemennya, bahwa Allah mengangkat penguasa-penguasa bagi masyarakat. Penguasa-penguasa ini mendapat pancaran Ilahi dan dikukuhkan dengan karamah-Nya. Hanya saja, dia tidak menjelaskan, dikukuhkan melalui pemilihan atau penunjukan. Sehingga sumber kekuasaan kepala negara adalah bukan berasal dari rakyat, tetapi dari Allah yang diberikan kepada orang pilihan-Nya. Dan tugas pemimpin negara itu adalah mengelola urusan rakyatnya dan bertindak sebagai hakim untuk menyelesaikan perselisihan di antara mereka. ${ }^{28}$

Lebih lanjut Ibn Abi Rabi' menjelakan, bahwa Allah telah memberi keistimewaan kepada para penguasa, dengan memuliakannya, memberi kedudukan penting di negaranya, dan disegani hamba-hamba Allah. Allah pun juga mewajibkan kepada para ulama untuk mengagungkan, memuliakan dan menghormati raja, sebagaimana Allah mewajibkan orang-orang yang beriman untuk mentaati para penguasa. ${ }^{29}$

24 Munawir Sjadzali, 1993, Islam dan Tata Negara, ajaran, sejarah dan pemikiran, UI-Press, Jakarta, cet. V, hlm. 41

25 Harun Nasution membagi sejarah Islam menjadi 3 bagian, yaitu : kelompok periode Klasik (650-1250 M), periode pertengahan (1250-1800 M), dan periode Modern (1800 M). lihat Harun Nasution, 1985, Islam Ditinjau Dari Berbagai Aspeknya, jilid I, UI-Press, Jakarta, hlm. 56-88

26 Munawir Sjadzali, 1993, Islam dan Tata Negara, ajaran, sejarah dan pemikiran, UI-Press, Jakarta, cet. V, hlm. 42

27 Munawir Sjadzali, 1993, Islam dan Tata Negara, ajaran, sejarah dan pemikiran, UI-Press, Jakarta, cet. V, hlm. 43-44; Muhammad Jalal Syaraf, 1978, al-Fikr al-Siyasi fi al-Islam; Syakhshiyyah wa Madzahib, Dar alJam iiyyah al-Mishriyyah, Iskandaria, hlm. 209

28 Ibn Abi Rabi', 1983, Suluk al-Malik fi Tadbir al-Mamalik, ditahqiq oleh $\underline{\text { Hamid }}$ 'Abd Allah Rabi', Dar alSya'b, Kairo, hlm. 101

29 Ibn Abi Rabi', 1983, Suluk al-Malik fi Tadbir al-Mamalik, ditahqiq oleh Hamid 'Abd Allah Rabi', Dar alSya'b, Kairo, hlm. 406; Jalal Syaraf, 1978, al-Fikr al-Siyasi fi al-Islam; Syakhshiyyah wa Madzahib, Dar al-Jam'iyyah al-Mishriyyah, Iskandaria, hlm. 218 
Pemimpin masyarakat atau negara, demikian Ibn Abi Rabi', haruslah seorang manusia utama. Baginya, manusia utama adalah mereka yang memenuhi criteria sebagai berikut:

a. mempunyai kemampuan untuk mewujudkan kebahagiaan.

b. sehat tubuhnya.

c. mempunyai pemahaman dan penelaahan yang baik terhadap pendapat ulama yang mengetahui kandungan kitab suci.

d. daya ingatnya baik (kuat) dan tidak melupakan ilmu pengetahuan yang telah diperolehnya.

e. memiliki tingkat kecerdasan dan ketajaman berfikir yang baik, saat menghadapi suatu masalah.

f. berkemampuan olah vokal dengan baik.

g. mencintai ilmu dan suka belajar, serta mengambil pelajaran dari setiap kejadian.

h. tidak mempunyai karakteristik yang buruk dan membenci sesuatu, yang dapat mengakibatkan buruk bagi dirinya.

i. berjiwa besar, mencintai kemuliaan dan menjaga dirinya dari segala sesuatu yang membawa keburukan.

j. mencintai keadilan, kejujuran, dan orang-orang yang adil dan jujur; serta benci kepalsuan dan kebohongan.

k. percaya diri untuk merealisasikan cita-citanya, tidak takut mati, dan tidak punya jiwa yang lemah.

1. memandang rendah dunia dan hal-hal yang membawa kepada nilai-nilai keduniaan yang fana. ${ }^{30}$

Bentuk pemerintahan yang terbaik, masih menurut Ibn Abi Rabi', adalah bentuk pemerintahan monarkhi, yakni pemerintahan yang berpusat pada satu individu, yaitu seorang raja. ${ }^{31} \mathrm{Hal}$ ini didasarkan dengan pertimbangan, dengan banyaknya pemimpin, akan dapat melumpuhkan politik pemerintahan dan menimbulkan kekacauan. Karenanya, sebuah kota / negara atau masyarakat perlu dipimpin oleh seorang pemimpin yang kuat. ${ }^{32}$ Selain itu, sebuah negara perlu dipimpin seorang pemimpin, juga didasarkan dengan beberapa pertimbangan lain, seperti agar penguasa mempunyai kesempatan yang besar untuk menegakkan keadilan di antara warga negara; dapat menolak kezhaliman terhadap orang-orang yang mungkin dianiaya; mendorong warga negara untuk mewujudkan tujuannya yang luhur, sehingga setiap orang dapat bekerja untuk kepentingan dirinya dan kepentingan masyarakat. Bagi Ibn Abi Rabi', sebuah negara cukup dipimpin seorang penguasa yang mengelola dan merencanakan, agar tidak terjadi kesewenang-wenangan di antara warga masyarakat. Hal ini dimaksudkan, agar tiap-tiap anggota masyarakat dapat bekerja dan menghasilkan suatu produksi yang bermanfaat bagi kepentingan

30 Ibn Abi Rabi', 1983, Suluk al-Malik fi Tadbir al-Mamalik, ditahqiq oleh Hamid 'Abd Allah Rabi', Dar alSya'b, Kairo, hlm. 313

31 Ibn Abi Rabi', 1983, Suluk al-Malik fi Tadbir al-Mamalik, ditahqiq oleh $\underline{\text { Hamid }}$ 'Abd Allah Rabi', Dar alSya'b, Kairo, hlm. 103; Munawir Sjadzali, 1993, Islam dan Tata Negara, ajaran, sejarah dan pemikiran, UI-Press, Jakarta, cet. V, hlm. 46

32 Ibn Abi Rabi', 1983, Suluk al-Malik fi Tadbir al-Mamalik, ditahqiq oleh $\underline{\text { Hamid }}$ 'Abd Allah Rabi', Dar alSya'b, Kairo, hlm. 104; Jalal Syaraf, 1978, al-Fikr al-Siyasi fi al-Islam; Syakbshiyyah wa Madzahib, Dar al-Jam 'iyyah al-Mishriyyah, Iskandaria, hlm. 215 
dirinya dan kepentingan orang lain..$^{33}$

Sebuah negara dapat tegak, tegas Ibn Abi Rabi', jika komponen-komponen penting diperhatikan, yaitu : raja, rakyat, keadilan dan pengelolaan pemerintahan (administrasi negara).

Seorang raja setidaknya harus memenuhi 6 kriteria sebagai berikut : 1) dari segi keturunan, ia harus berasal dari keluarga raja dan dekat hubungan kekerabatannya dengan raja sebelumnya; 2) mempunyai cita-cita yang tinggi, yang dapat dibina melalui pendidikan akhlaq; 3) berpendirian tegas, yang bias dibina melalui penelaahan dan pembahasan tentang pola-pola pengelolaan negara yang dilakukan oleh para raja sebelumnya; 4) tegar saat menghadapi kesulitan; 5) memiliki sumber finansial yang cukup; 6) dan mempunyai pembantu-pembantu yang jujur. ${ }^{34}$

Berkaitan dengan keadilan, secara garis besar dapat dikelompokkan menjadi tiga bagian, yaitu : keadilan yang berhubungan dengan perbuatan seorang hamba yang berkenaan dengan hak Allah; keadilan yang berhubungan dengan perbuatan seseorang yang berkenaan dengan hak-hak terhadap sesamanya; dan keadilan yang berhubungan dengan perbuatan seseorang terhadapat hak-hak para pendahulu mereka.

Adapun indicator seseorang dapat dikatakan bersikap adil adalah 1) menepati janji dan amanah, serta dapat dipercaya; 2) bersifat penyayang dan terbebas dari sikap penipu;3) memelihara dan memperhatika janji-janjinya kepada orang lain; 4) jujur dalam segala tindakannya; 5) tidak melanggar ketentuan-ketentuan yang berlaku; 6) menempatkan segala seuatu pada tempatnya dan menyampaikan amanat pada yang berhak menerimanya. ${ }^{35}$

Selanjutnya, agar kekuasaan dan pengelolaan pemerintah berjalan secara efektif dan efesien, penyelenggara negara - masih menurut Ibn Abi Rabi' - harus memperhatikan hal-hal sebagai berikut : 1) tidak mengangkat pejabat negara yang tidak memiliki integritas kepribadian yang memadai dan membahayakan kerajaan; 2) tidak meminta fatwa atau saran kepada orang yang tidak dapat dipercaya, yang dapat membawa kehancuran negara; 3) tidak menyimpan atau menyampaikan rahasia kepada orang yang tidak dapat dipercaya; 4) tidak minta bantuan kepada orang yang tidak memiliki kemandirian, yan dapat merusak urusannya; 5) tidak meremehkan pejabat-pejabat negara, yang menunjukkan kelemahan pemikirannya; 6) tidak memberi tugas kepada orang-orang yang bodoh atau tidak mampu, yang dapat berakibat buruk. ${ }^{36}$

33 Jalal Syaraf, 1978, al-Fikr al-Siyasi fi al-Islam; Syakhshiyyah wa Madzahib, Dar al-Jam 'iyyah al-Mishriyyah, Iskandaria, hlm. 215; Supardi, 1997, Negara dan Pemerintah (Pemikiran Politik Ibn Abi Rabi'), Seri Tesis, PPs UIN Syarif Hidayatullah, Jakarta, hlm. 115-116

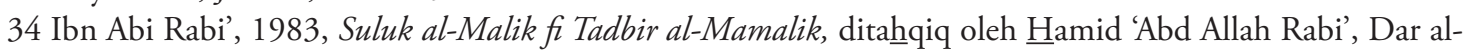
Sya 'b, Kairo, hlm. 407; Supardi, 1997, Negara dan Pemerintah (Pemikiran Politik Ibn Abi Rabi'), Seri Tesis, PPs UIN Syarif Hidayatullah, Jakarta, hlm. 118-119

35 Jalal Syaraf, 1978, al-Fikr al-Siyasi fi al-Islam; Syakhshiyyah wa Madzahib, Dar al-Jam 'iyyah al-Mishriyyah, Iskandaria, hlm. 228-229; Supardi, 1997, Negara dan Pemerintah (Pemikiran Politik Ibn Abi Rabi'), Seri Tesis, PPs UIN Syarif Hidayatullah, Jakarta, hlm. 125

36 Jalal Syaraf, 1978, al-Fikr al-Siyasi fi al-Islam; Syakhshiyyah wa Madzahib, Dar al-Jam 'iyyah al-Mishriyyah, Iskandaria, hlm. 229-230; Supardi, 1997, Negara dan Pemerintah (Pemikiran Politik Ibn Abi Rabi'), Seri Tesis, PPs UIN Syarif Hidayatullah, Jakarta, hlm. 126-127 


\section{Pemikiran al-Farabi}

Nama lengkapnya adalah Abu Nashr Muhammad Ibn Muhammad Ibn Uzalagh Ibn Tharkhan al-Farabi. Lahir di kota kecil bernama Wasij, wilayah Farab, termasuk kawasan Turkisan, tahun $257 \mathrm{H} / 870 \mathrm{M}$, dari pasangan ayah yang berkebangsaan Persia dan ibu berkebangsaan Turki. Wafat tahun 339 H/950 M. Pemikiran-pemikiran politiknya dapat dilihat dalam karya-karyanya, antara lain : Arầ Ahl al-Madînah al-Fadlîlah (pandangan-pandangan para penghuni negara yang utama), Tahbshil al-Sa'adah (jalan mencapai kebahagiaan), dan alSiyâsah al-Madaniyyah (politik kenegaraan). ${ }^{37}$

Sebagaimana Ibn Abi Rabi', berkaitan dengan asal usul kota atau sebuah negara, alFarabi juga berpendapat, bahwa manusia adalah makhluk sosial, yang secara alami mempunyai kecenderungan untuk hidup bermasyarakat. Karena, untuk memenuhi kebutuhannya, ia membutuhkan bantuan dan kerja sama dengan pihak lain. Dan tujuan bermasyarakat ini, tidak semata-mata untuk memenuhi kebutuhan pokok hidup ini saja, tetapi juga untuk menghasilkan kelengkapan hidup bagi kebahagiaan manusia. ${ }^{38}$

Dari kecenderungan alami manusia untuk bermasyarakat, lahirlah berbagai macam masyarakat; ada yang sempurna (al-kâmilah) dan ada yang tidak sempurna (ghayr al-kâmilah).

Masyarakat yang sempurna, menurut al-Farabi, terbagi menjadi tiga macam, yaitu : masyarakat sempurna besar, masyarakat sempurna sedang, dan masyarakat sempurna kecil. Adapun masyarakat sempurna besar adalah gabungan banyak bangsa yang sepakat untuk bergabung dan saling membantu serta kerja sama; atau dapat diistilahkan dengan perserikatan bangsa-bangsa. Masyarakat sempurna sedang adalah masyarakat yang terdiri dari satu bangsa yang menghuni satu wilayah di bumi ini; atau dapat disebut dengan negara nasional. sedangkan masyarakat sempurna kecil adalah masyarakat yang terdiri dari para penghuni satu kota; atau diistilahkan dengan negara-kota. ${ }^{39}$

Adapun masyarakat yang tidak sempurna adalah kehidupan social di tingkat desa, kampung lorong dan keluarga, dan di antara tiga pergaulan yang tidak atau belum sempurna itu. Karenanya, kehidupan social dalam rumah atau keluarga adalah masyarakat yang paling tidak sempurna. Keluarga merupakan bagian dari masyarakat lorong; masyarakat lorong merupakan bagian masyarakat kampung; dan masyarakat kampung merupakan bagian dari masyarakat negara-kota. Hanya bedanya, kampung merupakan bagian negara-kota, sedangkan desa hanya merupakan pelengkap untu melayani kebutuhan negara-kota..$^{40}$ Dari sini nampak, al-Farabi tidak menganggap tiga unit pergaulan social tersebut sebagai masyarakat yang sempurna, karena tidak cukup kuat untuk berswasembada dan mandiri dalam rangka memenuhi kebutuhan para

37 Munawir Sjadzali, 1993, Islam dan Tata Negara, ajaran, sejarah dan pemikiran, UI-Press, Jakarta, cet. V, hlm. 49

38 Al-Farabi, 1906, Kitab Ara' Ahl al-Madinah al-Fadlilah, Mathba'ah al-Sa'adah, Mesir, cet. I, hlm. 77-78; Munawir Sjadzali, 1993, Islam dan Tata Negara, ajaran, sejarah dan pemikiran, UI-Press, Jakarta, cet. V, hlm. 50-51 39 Al-Farabi, 1906, Kitab Ara' Ahl al-Madinah al-Fadlilah, Mathba'ah al-Sa'adah, Mesir, cet. I, hlm. 78; Munawir Sjadzali, 1993, Islam dan Tata Negara, ajaran, sejarah dan pemikiran, UI-Press, Jakarta, cet. V, hlm. 51

40 Al-Farabi, 1906, Kitab Ara' Ahl al-Madinah al-Fadlilah, Mathba'ah al-Sa'adah, Mesir, cet. I, hlm. 78; Munawir Sjadzali, 1993, Islam dan Tata Negara, ajaran, sejarah dan pemikiran, UI-Press, Jakarta, cet. V,. hlm. 52 
warganya, baik berkaitan dengan masalah ekonomi, social, budaya maupun spiritual. ${ }^{41}$

Selanjutnya, kepala negara, lanjut al-Farabi, haruslah seorang pemimpin yang arif dan bijaksana, yang memiliki dua belas kualitas luhur, yang sebagian telah ada sewaktu lahir sebagai watak yang alami atau tabiat yang fitri, namun yang lain perlu dikembangkan melalui pengajaran yang terarah, pendidikan serta latihan yang menyeluruh. Baginya, pemimpin negara tidak harus seorang filsuf yang mendapat kemakrifatan atau kearifan melalui pikiran dan rasio, tetapi juga dapat seorang nabi yang mendapat kebenaran lewat wahyu. Adapun kedua belas syarat pemimpin itu antara lain : 1) lengkap anggota tubuhnya; 2) mempunyai kemampuan pemahaman yang baik; 3) kuat hafalannya dan tinggi intelegensianya; 4) pandai mengemukakan pendapatnya dan mudah dimengerti uraiannya; 5) mencinta pendidikan dan gemar mengajar; 6) tidak rakus terhadap makanan dan makanan serta wanita; 7) mencinta kejujuran dan membenci kebohongan; 8) berjiwa besar dan berbudi luhur; 9) tidak memandang penting terhadap kekayaan dan kesenangan-kesenangan dunia; 10) mencintai keadilan dan membenci kezhaliman; 11) tanggap dan tidak sukar, bila diajak menegakkan keadilan, dan sulit bila diajak untuk melakukan atau menyetujui tindakan keji dan kotor; 12) kuat pendiriannya terhadap hal-hal yang menurutnya harus dikerjakan, penuh keberanian, tinggi antusiasme, tidak penakut atau berjiwa lemah. ${ }^{42}$

Karena untuk mendapatkan orang yang memiliki semua kualitas luhur tersebut adalah sangat sulit dan jarang, maka - masih menurut al-Farabi - jika terdapat lebih dari satu, maka yang diangkat menjadi kepala negara adalah seorang saja. Tetapi jika tidak terdapat sama sekali yang memenuhi criteria di atas, maka pimpinan negara dapat dipikul secara kolektif antara sejulah warga negara yang termasuk kelas pemimpin.43

\section{Pemikiran al-Mawardi}

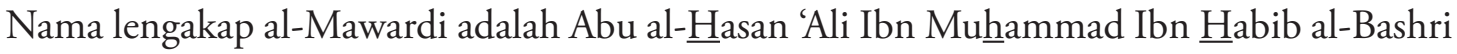
al-Mawardi (364 H/975 M - 450 H/1059 M). Ia adalah seorang pemikir Islam terkenal, tokoh terkemuka madzhab Syafi'i, dan pejabat tinggi yang besar pengaruhnya pada masa pemerintahan Abbasiyyah. Setelah menjalani hidup dengan cara berpindah-pindah, dari satu kota ke kota lainnya sebagai hakim, akhirnya dia kembali dan menetap di Baghdad, dan mendapat kedudukan terhormat pada pemerintahan khalifah Qadir. ${ }^{44}$

Diantara pemikiran politik al-Mawardi yang terkenal adalah tentang khilafah atau imâmah. ${ }^{45}$

41 Munawir Sjadzali, 1993, Islam dan Tata Negara, ajaran, sejarah dan pemikiran, UI-Press, Jakarta, cet. V,. hlm. 52

42 Al-Farabi, 1906, Kitab Ara' Ahl al-Madinah al-Fadlilah, Mathba'ah al-Sa'adah, Mesir, cet. I, hlm. 87-88; Munawir Sjadzali, 1993, Islam dan Tata Negara, ajaran, sejarah dan pemikiran, UI-Press, Jakarta, cet. V,. hlm. 56

43 Al-Farabi, 1906, Kitab Ara' Ahl al-Madinah al-Fadlilah, Mathba'ah al-Sa'adah, Mesir, cet. I, hlm. 88-89; Munawir Sjadzali, 1993, Islam dan Tata Negara, ajaran, sejarah dan pemikiran, UI-Press, Jakarta, cet. V,.hlm. 56

44 Munawir Sjadzali, 1993, Islam dan Tata Negara, ajaran, sejarah dan pemikiran, UI-Press, Jakarta, cet. V, hlm. 58

45 Kata imâmah sering digunakan dalam pemikiran politik Islam secara bergantian dan secara sinonim, dengan kata khalifah. Menurut Mikhail, sebagaimana dikutip oleh Din Syamsuddin, pilihan al-Mawardi dan para penulis sunni lain, yang lebih condong menggunakan kata imâmah daripada khalifah, berawal dari kenyataan, 
Baginya, imâmah diartikan sebagai pengganti kedudukan Nabi, yang melestarikan agama dan menyelenggarakan kepentingan duniawi. ${ }^{46}$

Dan eksistensi imâmah, bagi al-Mawardi, adalah penting dan wajib. Hanya saja, kewajiban itu, apakah berdasarkan akal atau syara' masih dalam perdebatan di kalangan para ulama'. Ada yang mengatakan, imâmah wajib berdasarkan pertimbangan rasionalitas. Artinya, adanya imâmah adalah untuk menjaga ketertiban dan stabilitas keamanan, serta menghindarkan dari tindakan-tindakan anarkis dan pertentangan dan permusuhan. Namun ada juga yang berpendapat, kewajiban itu adalah ditetapkan oleh syara', berdasarkan QS. al-Nisa' ayat 59.47

Lembaga imâmah ini, menurut al-Mawardi, mempunyai tugas dan tujuan umum, yaitu : 1) memelihara dan mempertahankan syari'at berdasarkan prinsip-prinsip yang ditetapkan dan sesuatu yang menjadi ijma' oleh generasi awal umat Islam; 2) melaksanakan ketentuan hokum di antara oknum-oknum yang sedang bersengketa atau berselisih, dan mewujudkan keadilan antara yang teraniaya maupun yang menganiaya; 3) melindungi wilayah Islam dan memelihara kehormatan rakyat, agar memiliki kemerdekaanjiwa dan harta mereka; 4) memelihara hakhak rakyat dan hokum Tuhan; 5) mengkonsolidasikan kekuatan untuk melawan musuh; 6) berjihad terhadap orang-orang yang menentang Islam, setalah ada dakwah atau seruan, agar mereka mengakui eksistensi Islam; 7) memungut pajak dan sedekah menurut ketentuan syari'at, nash dan ijtihad; 8) mengatur pemanfaatan harta baitul mal secara efektif; 9) minta nasehat dan pandangan dari tokoh-tokoh masyarakat yang terpercaya; 10) dalam mengatur umat dan memelihara agama, pemerintah bersama kepala negara harus langsung menangani dan meneliti keadaan yang sesungguhnya. ${ }^{48}$ Selain itu, lembaga ini juga bertugas mewujudkan kemaslahatankemaslahan dan sarana-sarana yang dapat mewujudkan kemaslahatan tersebut. ${ }^{49}$

Seorang imam dapat dipilih melalui dua cara, yaitu : melalui pemilihan sebuah badan yang disebut abl al-'aqd wa al-hal atau ahl al-ikhtiyâr dan melalui pilihan imam sebelumnya. ${ }^{50}$

Badan yang memilih imam di atas, setidaknya harus memenuhi tiga kriteria, yaitu : 1) berlaku adil (al-'adâlah) dengan segala persyaratannya dalam segala sikap dan tingkah lakunya; 2) memiliki pengetahuan, yang dengannya dapat mengetahui siapa yang berhak menjadi kepala negara, berdasarkan kualifikasi yang ditentukan; 3) memiliki wawasan dan kearifan (al-ra'y wa

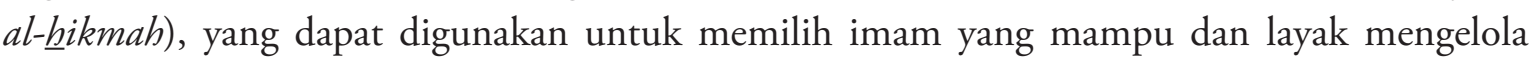

bahwa kaum sunni menulis untuk merespons kaum syiah yang lebih memilih menggunakan term imâmah daripada khilafah, untuk menunjuk pada pemimpin-pemimpin agung politik-keagamaan mereka. John H. Mikhail, 1968, Mawardi: A Study in Islamic Political Thaought, Seri Disertasi Ph.D, Harvard University, hlm. 32; Din Syamsuddin, 2001, Islam dan Politik Era Orde Baru, Logos, Jakarta, cet. I, hlm. 95

46 Al-Mawardi, t.th., al-A $\underline{h} k a ̂ m$ al-Sulthâniyyah, Dar al-Kutub al-'Ilmiyyah, Bairut, hlm. 5

47 Al-Mawardi, t.th., al-Ahkâm al-Sulthaniyyah, Dar al-Kutub al-'Ilmiyyah, Bairut, hlm. 5 Arti ayat tersebut adalah : "Hai orang-orang yang beriman, ta'atilah Allah dan ta'atilah Rasul (Nya), dan ulil amri di antara kamu. Kemudian jika kamu berlainan pendapat tentang sesuatu, maka kembalikanlah ia kepada Allah (Al Qur'an) dan Rasul (sunnahnya), jika kamu benar-benar beriman kepada Allah dan hari kemudian. Yang demikian itu lebih utama (bagimu) dan lebih baik akibatnya."

48 Al-Mawardi, t.th., al-Ahkâm al-Sulthâniyyah, Dar al-Kutub al-'Ilmiyyah, Bairut, hlm. 15-16

49 Al-Mawardi, t.th., Adâb al-Dun-yâ wa al-Dîn, Dar al-Fikr, Bairut, hlm. 139

50 Al-Mawardi, t.th., al-A $\underline{h}$ âm al-Sulthâniyyah, Dar al-Kutub al-'Ilmiyyah, Bairut, hlm. 6-7 
urusan negara dan rakyat. Dan anggota-anggotanya tidak harus terdiri dari mereka yang hanya berada dalam negara imam atau ibukota. ${ }^{51}$

Adapun calon imam yang layak dipilih, lanjut al-Mawardi, harus memenuhi syarat-syarat berikut ini: 1) sikap adil (al-'adâlah) dengan segala persyaratannya; 2) memiliki pengetahuan yang dapat dipergunakan untuk mengambil ijtihad atau keputusan dalam mengahadapi problematika negara; 3) sehat pendengaran, penglihatan dan lisannya; 4) utuh anggota-anggota badannya; 5) mempunyai kebijaksanaan (al-ra'y al-mufdli) dalam mengatur kehidupan rakyat dan kepentingan umum; 6) mempunyai keberanian untuk memerangi musuh; 7) berketurunan suku Quraisy. ${ }^{52}$

\section{Pemikiran Ibn Taymiyyah}

Nama lengkapnya adalah Taqî al-Dîn Abû al-'Abâs Ahmad ibn 'Abd al-Halîm Ibn 'Abd alSalâm Ibn 'Abd Allah Ibn Taimiyyah al-Harânî al-Hanbalî. Lahir di kota Harran Mesopotamia Utara, pada hari Senin, tanggal 10 Rabî‘ul Awal tahun 661 H., bertepatan dengan 22 Januari 1263 M., dan meninggal di Damaskus pada tanggal 20 Dzulqa'dah 728 H., bertepatan dengan 26 September $1328 \mathrm{M}^{53}$. Ayahnya adalah seorang ulama besar yang mempunyai kedudukan tinggi di masjid jami` Damascus. Ia bertindak sebagai khatib dan imam di masjid itu, sekaligus sebagai muallim pelajaran tafsir dan hadis. Disamping itu dia juga sebagai direktur Madrasah Dar al-Hadis al-Sukkariyyah, salah satu lembaga pendidikan mazhab Hanbali yang tergolong sangat maju dan bermutu pada waktu itu. Di sinilah Abdul Halim mendidik Ibn Taimiyyah. ${ }^{54}$ Dan pemikiran politiknya terlihat dalam karyanya yang berjudul al-Siyâsah al-Syar'iyyah fi Ishlâh alRâ'i wa al-Ra iyyah (politik yang berdasarkan syari'ah bagi perbaikan penggembala dan gembala).

Orientasi pemikiran politik Ibn Taymiyyah adalah bersendikan agama. Hal ini terlihat dari judul buku di atas atau pun isi mukaddimahnya, yang mendasarkan teori etik politiknya dengan ayat al-Qur'an, surat al-Nisa' ayat 58-59.55 Dari dua ayat tersebut, setidaknya ada empat pesan yang terkandung di dalamnya : 1) perintah menunaikan amanat; 2) perintah berlaku adil dalam menetapkan hokum; 3) perintah taat kepada Allah, Rasul dan Ulil Amri; dan 4) perintah menyelesaikan perselisihan dengan mengembalikannya kepada Allah dan Rasul-Nya. ${ }^{56}$

51 Al-Mawardi, t.th., al-Ahkkâm al-Sulthâniyyah, Dar al-Kutub al-'Ilmiyyah, Bairut, hlm. 6

52 Al-Mawardi, t.th., al-A $\underline{h} k \hat{a} m$ al-Sulthâniyyah, Dar al-Kutub al-'Ilmiyyah, Bairut, hlm. 6

53 Ibn Taimiyyah dan Muhammad Ibn Abd al-Wahâb, 1991, Majmû́ah al-Tauhî̀d, Dar al-Fikr, Bairut, hlm. 325; Muhammad Abu Zahrah, t.th., Ibn Taimiyyah, Hayûtuh wa 'Ashruh, Dar al-Fikr al-'Arabi, Bairut, hlm. 10; B. Lewis, et. al. (edit), 1965, The Encyclopaedia of Islam, E.J. Brill, Leiden, Jilid III, hlm. 951

54 B. Lewis, et. al. (edit), 1965, The Encyclopaedia of Islam, E.J. Brill, Leiden, Jilid III, hlm. 951

55 Artinya : Sesungguhnya Allah menyuruh kamu menyampaikan amanat kepada yang berhak menerimanya, dan (menyuruh kamu) apabila menetapkan hukum di antara manusia supaya kamu menetapkan dengan adil. Sesungguhnya Allah memberi pengajaran yang sebaik-baiknya kepadamu. Sesungguhnya Allah adalah Maha Mendengar lagi Maha Melihat.(58) Hai orang-orang yang beriman, ta'atilah Allah dan ta'atilah Rasul (Nya), dan ulil amri di antara kamu. Kemudian jika kamu berlainan pendapat tentang sesuatu, maka kembalikanlah ia kepada Allah (Al Qur'an) dan Rasul (sunnahnya), jika kamu benar-benar beriman kepada Allah dan hari kemudian. Yang demikian itu lebih utama (bagimu) dan lebih baik akibatnya.(59); Ibn Taymiyyah, 1387, al-Siyâsah al-Syariyyah fi Ishlâh al-Rấi wa al-Ra'iyyah, al-Mathba'ah al-Salafiyyah, Kairo, hlm. 3-4

56 lihat juga M. Arskal Salim GP, 1999, Etika Intervensi Negara, Perspektif Etika Politik Ibn Taimiyah, Logos, Jakarta, hlm. 76 
Namun di lain tempat, Ibn Taymiyyah menyatakan, bahwa perintah menunaikan amanat dan perintah berlaku adil merupakan dua prinsip etik utama dan paling dominan dalam alsiyâsah-nya..$^{57}$

Tentang istilah amanat, menurut Ibn Taymiyyah, mencakup dua konsep, yaitu kekuasaan (politik) dan harta benda (ekonomi). ${ }^{58}$ Kekuasaan merupakan amanat yang harus ditunaikan. Dan karenanya, seorang pemimpin juga harus mempunyai sifat amanah. Dia dituntut untuk berlaku amanah dalam melaksanakan tugas dan menyelesaikannya dengan sebaik-baiknya. ${ }^{59}$

Berkaitan dengan kekuasaan politik, amanah menuntut keharusan menunaikan amanat sebagai bentuk tanggung jawabnya, baik amanat itu berasal dari Tuhan ataupun dari sesama manusia. Sedangkan amanah yang berhubungan dengan harta benda ekonomi, amanah berarti keharusan mengelola kekayaan negara secara proporsional dan bertanggung jawab untuk kemashlahatan rakyat. $^{60}$

Dalam beberapa bagian tulisannya dalam al-Siyâsah, Ibn Taymiyyah mengungkapkan beberapa kezhaliman ekonomi yang secara substantif mengindikasikan persoalan etis.

Pertama, pemerintah dilarang merampas atau mengambil harta benda rakyat, yang bukan haknya. Namun bila ada harta benda rakyat yang diperoleh dengan cara yang tidak halal, maka harus dikembaikan oleh pemerintah kepada pemiliknya. ${ }^{61}$

Kedua, para pejabat hendaknya tidak menerima hadiah dari siapapun, saat melaksanakan tugas. Karena hadiah itu dapat menimbulkan dampak-dampak negatif yang tidak diinginkan. ${ }^{62}$

Ketiga, harta benda yang sudah terlanjur disita oleh negara secara illegal, dan sudah diketahui, bahwa harta itu tidak ada pemiliknya, maka harta dimaksud harus digunakan untuk kepentingan umum, seperti untuk sektor pertahanan keamanan dan pembayaran gaji tentara. ${ }^{63}$

Keempat, dalam pembangunan, yang harus diperhatikan adalah asas kemaslahatan secara sempurna dan menekan seminimal mungkin timbulnya kerusakan. ${ }^{64}$

57 Ibn Taymiyyah, 1387, al-Siyâsah al-Syariiyyah fi Ishlâh al-Rấi wa al-Ra'iyyah, al-Mathba'ah al-Salafiyyah, Kairo, hlm. 5

58 Ibn Taymiyyah, 1387, al-Siyâsah al-Syariiyyah fi Ishlâh al-Rấi wa al-Ra'iyyah, al-Mathba'ah al-Salafiyyah, Kairo, hlm. 6

59 M. Arskal Salim GP999, Etika Intervensi Negara, Perspektif Etika Politik Ibn Taimiyah, Logos, Jakarta, hlm. 77

60 M. Arskal Salim GP999, Etika Intervensi Negara, Perspektif Etika Politik Ibn Taimiyah, Logos, Jakarta, hlm. 77

61 Ibn Taymiyyah, 1387, al-Siyâsah al-Syariiyyah fi Ishlâh al-Rấi wa al-Ra iyyah, al-Mathba'ah al-Salafiyyah, Kairo, hlm. 42-44

62 Ibn Taymiyyah, 1387, al-Siyâsah al-Syariyyah fi Ishlâh al-Rấi wa al-Ra'iyyah, al-Mathba'ah al-Salafiyyah, Kairo, hlm. 44-47

63 Ibn Taymiyyah, 1387, al-Siyâsah al-Syariiyyah fi Ishlâh al-Rấi wa al-Ra'iyyah, al-Mathba'ah al-Salafiyyah, Kairo, hlm. 48

64 Ibn Taymiyyah, 1387, al-Siyâsah al-Syar'iyyah fi Ishlâh al-Rấi wa al-Ra'iyyah, al-Mathba'ah al-Salafiyyah, Kairo, hlm. 49; lihat juga M. Arskal Salim GP, 1999, Etika Intervensi Negara, Perspektif Etika Politik Ibn Taimiyah, Logos, Jakarta, hlm. 77-78 
Tentang prinsip keadilan, bagi Ibn Taymiyyah, merupakan prinsip fundamental sebuah pemerintahan. Karena pentingnya keadilan ini, Ibn Taymiyyah hingga berpendapat, bahwa pemerintah yang adil, walaupun dipimpin oleh seorang kafir adalah lebih baik daripada pemerintahan muslim tetapi berlaku zhalim. Karena, keadilan walaupun disertai dengan kekafiran, masih memungkin adanya kesinambungan kehidupan dunia, tetapi sebaliknya, kezhaliman meskipun dengan keislamannya, akan sulit mempertahankan kehidupan dunia. ${ }^{65}$

\section{Etika Politik : Antara Normatifitas dan Realitas}

Politik riil yang terjadi adalah pertarungan antar kekuatan masing-masing partai. Seringkali filsafat politik ataupun etika politik dianggap dunia ideal yang tidak mencerminkan realitas politik yang ada, atau pun sebaliknya.

Berbagai peristiwa kekerasan, politik uang dan korupsi, sangat mendominasi kehidupan politik di Indonesia. Peristiwa tragis juga pernah terjadi, kerusuhan disertai penjarahan, penganiayaan dan pemerkosaan (Mei 1998). Kekerasan yang lebih kejam berlangsung dalam konflik antar etnis dan antar agama (pontianak, Sampit, Ambon, Poso). Semua itu meninggalkan korban, trauma psikologis, pengungsian, dan penderitaan berkepanjangan. Serentetan kejadian itu, tidaklah terjadi secara spontan atau peristiwa insidental belaka. Namun di balik peristiwa itu, tidak lepas dari praktek politik kekuasaan kelompok tertentu.

Adalah sangat sulit, jika tragedi-tragedi itu tidak dikaitkan dengan pertarungan elit politik untuk memperebutkan kekuasaan. Meskipun demikian, rekayasa politik tidak akan memancing kekerasan dengan mudah, jika tidak ada masalah-masalah yang melilit mereka sebelumnya. Seperti masalah ketidak adilan dan kebencian korban ketidakadilan adalah konkrit adanya, yang membuat mereka semakin termarjinalkan. Kesenjangan ekonomi antara si kaya dan si miskin terlalu jauh; persoalan-persoalan sosial yang semakin komplek dan berimbas pada kebijakan yang tidak populis, seperti banyaknya anak putus sekolah, pengangguran, kemiskinan, dan penggusuran. Bentuk marginalisai ini, pada saatnya akan memancing radikalisme dalam menuntut keadilan. Dan radikalisasi menjadi kuat, karena kesadaran yang semakin kuat pada diri mereka sebagai korban. Identitas korban akan semakin mengkristal, ketika agama menawarkan pendasaran ideologis. Situasi frustasi semacam ini diperparah oleh kebencian antara pemeluk agama, yang sungguh ada dan dapat dirasakan. Prasangka buruk terhadap pemeluk agama lain sering kali muncul dan sengaja dihembuskan oleh pihak-pihak tertentu yang akan memanfaatkan setiap ada chaos (kekacauan), walaupun tidak sedikit yang menjalin hubungan secara harmonis dan membangun dialog. ${ }^{66}$

Ketika berbagai bentuk peristiwa kekerasan itu mulai mereda, yang mencuat ke permukaan sekarang adalah politik uang dan korupsi. Adanya praktek politik uang, biasa digunakan untuk meraih kekuasaan, atau untuk melanggengkan kekuasaan. Hal ini bisa dilihat dalam proses pilkada di daerah-daerah, yang sarat dengan politik uang, walaupun sulit dibuktikan

65 M. Arskal Salim GP, 1999, Etika Intervensi Negara, Perspektif Etika Politik Ibn Taimiyah, Logos, Jakarta, hlm. 80

66 Haryatmoko, 2004, Etika Politik dan Kekerasan, Kompas, Jakarta, cet. II, hlm. x 
secara empiris. Meskipun akhir-akhir ini, KPK sering menangani kasus tangkap tangan saat terjadi penyuapan kepala daerah dan anggota dewan. Untuk melanggengkan kekuasaan itu, dibutuhkan berbagai fasilitas penopangnya, terutama ekonomi. Korupsi itu sendiri merupakan bentuk penyalahgunaan kekuasaan oleh oknumnya.

Demikian halnya, saat para caleg atau calon kepala daerah berkampanye, tindak money politic pun terlihat di sana dengan berbagai bentuk yang beragam. Hal itu bisa dilihat, misalnya dari cara kampanye para caleg yang membagi-bagikan tas atau kaos bergambar caleg yang bersangkutan sebagai bentuk 'hadiah' atau 'kenang-kenang'; atau membagi-bagi uang kepada para calon pemilih di daerah pemilihannya. Demikian halnya dengan para calon kepala daerah. Saat berkampanye, banyak di antara mereka yang mengunjungi lembaga-lembaga pendidikan, baik pendidikan formal atau tradisional, yang nota bene banyak masanya. Saat berkunjung pun, tak segan-segan, mereka mengeluarkan banyak duit, untuk 'menyumbang' atau sekedar memberi 'hadiah' kepada sang kiai atau pimpinan lembaga tersebut. Lebih-lebih, jika kiai tersebut adalah pimpinan tarekat, yang mempunyai banyak masa, maka antusiasme para calon kepala daerah untuk mendekatinya sangat terlihat. Namun di balik pendekatan dan pemberian 'bantuan' tersebut, terselip pesan sponsor politis, "pilihlah saya...”. Begitulah kira-kira kondisi perpolitikan Indonesia dewasa ini.

Jika melihat realitas politik yang demikian memilukan ini, seolah-olah berbicara politik dalam tataran normatif, sebagaimana etika politik, memberi kesan naïf dan absurd. Karena kehidupan politik, pada dasarnya merupakan pertarungan kekuatan antar kelompok politik tertentu dan mempunyai kecenderungan untuk menghalalkan segala cara, asal tujuan tercapai. Dan sebagaimana kita ketahui, dalam kehidupan politik, kepentingan-kepentingan politik sesaat, yang menguntungkan kelompok tertentu (penguasa) - walaupun merugikan kepentingan rakyat - kerap kali terjadi, tanpa menghiraukan kritik dan koreksi orang lain.

Manuver-manuver politik yang dilakukan oleh para elit politik, sering tidak sejalan dengan etika politik yang telah dibangun oleh para pakarnya. Karena, politik sangat fleksibel sifatnya, sehingga seolah tidak ada tatanan normatif politik yang baku, kecuali hukum undang-undang yang kerapkali mengundang banyak kontroversi interpretasi.

Namun tidak harus menyerah begitu saja. Adanya tindak kekerasan, politik uang dan korupsi, serta penyalahgunaan kekuasaan, yang sangat melekat dengan praktek kekuasaan, hendaknya justru semakin menyadarkan kita, betapa pentingnya penerapan etika politik secara teoritik ke dalam kehidupan politik secara riil, walaupun aplikasinya masih dalam proses, untuk tidak mengatakan tidak mungkin.

Sebagaimana telah disinggung di atas, bahwa etika politik bukanlah akan mengkhutbahi para politikus secara langsung, namun setidaknya, adanya etika politik yang ada, sebagaimana pemikiran politik yang telah dibangun oleh para pemikir muslim klasik dan pertengahan di atas, dapat dijadikan sebagai bahan renungan untuk membangun iklim politik yang lebih etis dan mengevaluasi kinerja pemerintahan yang sedang berlangsung, yang akan dapat dijadikan sebagai 
tolok ukur untuk memilih pemimpin masa yang akan datang. Dengan pemahaman etika politik yang ada, diharapkan masyarakat akan menjadi lebih dewasa dalam hal politik.

\section{E. Penutup}

Secara general, etika politik yang telah diungkapkan dan dibangun oleh para pemikir muslim di atas, sangatlah ideal dalam kehidupan berpolitik, meskipun ada beberapa pemikiran, yang apabila diterapkan di negara Indonesia - negara demokrasi, bukan negara Islam - tidak dapat dilaksanakan, atau membutuhkan reinterpretasi ulang. Namun, dari berbagai syarat yang diajukan oleh mereka bagi seorang pemimpin, misalnya, rasanya sangat sulit untuk diwujudkan atau dimiliki oleh satu orang. Karenanya, penulis setuju dengan pemikiran al-Farabi yang memberi solusi, agar kepemimpinan dipegang secara kolektif, dengan mempertimbangkan kapabilitasnya masing-masing.

Dalam etika politik di atas, setidaknya ada beberapa konsep umum yang sangat ideal untuk diterapkan dalam kehidupan politik. Yakni ; kapabilitas pribadi pemimpin, keadilan, kejujuran, penyampaian amanat pada haknya, apresiasi terhadap keilmuan dan membela kepentingan rakyat banyak (yang tertindas) di atas kepentingan pribadi dan golongan. Setiap pemerintahan, dimanapun dan kapanpun, yang tidak menghiraukan etika-etika politik, niscaya kehancuran akan selalu menghantuinya.

Jika dalam setiap aksi politik, yang berkaitan erat secara langsung dengan perilaku politikus, selalu mempertimbangan dan menggunakan nilai-nilai etika politik, maka kehidupan panggung politik yang ada, akan membentuk budaya politik yang lebih santun, yang hasilnya dapat dirasakan oleh rakyatnya secara langsung.

\section{Bibiliografi}

Abu Zahrah, Muhammad, t.th., Ibn Taimiyyah, Haŷ̀tuh wa 'Ashruh, Dar al-Fikr al-'Arabi, Bairut

Bertens, K., 2000, Etika, Gramedia, Jakarta, cet. V

Esposito, John L, (Ed), 1995, The Oxford Encyclopedia of The Modern Islamic World, Oxford University Press, New York, vol. 1

Al-Farabi, 1906, Kitab Arầ Ahl al-Madînah al-Fadlîlah, Mathba'ah al-Sa'adah, Mesir, cet. I

Haryatmoko, 2004, Etika Politik dan Kekerasan, Kompas, Jakarta, cet. II

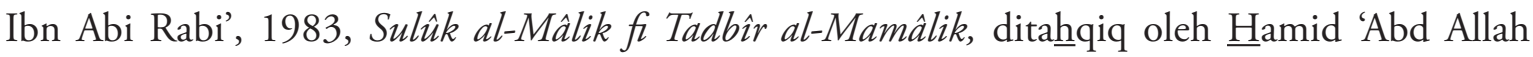
Rabi', Dar al-Sya'b, Kairo

Ibn Manzhûr, Jamâl al-Dîn Muhammad Ibn Mukarram al-Anshârî, 1968, Lisân al-Arab, Dâr 
al-Masyriq, Bairut

Ibn Taimiyyah dan Muhammad Ibn Abd al-Wahâb, 1991, Majmû́ah al-Tauhî̀d, Dar al-Fikr, Bairut

-------, 1387, al-Siyâsah al-Syar'iyyah fi Ishlâh al-Ra'i wa al-Ra iyyah, al-Mathba'ah al-Salafiyyah, Kairo

Khallâf, Abd al-Wahhâb, 1977, al-Siyâsah al-Syar iyyah, Dâr al-Anshâr, Kairo

Lewis, B., et. al. (edit), 1965, The Encyclopaedia of Islam, E.J. Brill, Leiden

Ma'lûf, Luwîs, 1986, al-Munjid fì al-Lughah wa al-A lâm, Dâr al-Masyriq, Bairut

Al-Mawardi, t.th., al-A $\underline{h} k \hat{a} m$ al-Sulthâniyyah, Dâr al-Kutub al-'Ilmiyyah, Bairut

---------, t.th., Adâb al-Dun-yâ wa al-Dîn, Dâr al-Fikr, Bairut

Nasution, Harun, 1985, Islam Ditinjau Dari Berbagai Aspeknya, UI-Press, Jakarta, cet. V

Pulungan, Suyuthi, J., 1999, Fiqih Siyasah, Ajaran Sejarah dan Pemikiran, Raja Grafindo, Jakarta, cet. IV

Al-Qardhawi, Yusuf, 1999, Pedoman Bernegara Dalam Perspektif Islam, terj. Kathur Suhardi, Pustaka al-Kautsar, Jakarta, cet. II

Salim, Arskal, GP. M., 1999, Etika Intervensi Negara, Perspektif Etika Politik Ibn Taimiyah, Logos, Jakarta

Sjadzali, Munawir, 1993, Islam dan Tata Negara, ajaran, sejarah dan pemikiran, UI-Press, Jakarta, cet. V

Suseno, Franz Magnis, 2003, Etika Politik, Gramedia, Jakarta, cet. VII

Syaraf, Muhammad Jalal, 1978, al-Fikr al-Siyâsî fî al-Islâm; Syakhshiyyah wa Madzâhib,Dar alJam iyyah al-Mishriyyah, Iskandaria

Syamsuddin, Din, 2001, Islam dan Politik Era Orde Baru, Logos, Jakarta, cet. I

Tim Penyusun Kamus Pusat Pembinaan dan Pengembangan Bahasa, Kamus Besar bahasa Indonesia, Departemen Pendidikan dan Kebudayaan, jakarta : Balai Pustaka, 1988, cet. I 